\title{
MATERNAL RISK FACTORS OF PERINATAL WOMEN COMPLICATIONS WITH THE URINARY SYSTEM DISEASES
}

\author{
Lidiia Melenchuk \\ Ph.D., Assistant Professor, Institute of Hereditary Pathology \\ of the National Academy of Medical Sciences of Ukraine, Ukraine \\ e-mail: Lidycja@gmail.com, orcid.org/0000-0001-5318-9992 \\ Yevheniya Sharhorodska \\ Ph.D., Senior Researcher, Institute of Hereditary Pathology \\ of the National Academy of Medical Sciences of Ukraine, Ukraine \\ e-mail: gendoctor86@gmail.com,orcid.org/0000-0003-0240-4765
}

\section{Summary}

The aim of the study was to determine the maternal factors of perinatal complications in women with diseases of the urinary system. A group of women with pathology of the urinary system were studied during the course and completion of pregnancy. The complications in childbirth condition of newborns in comparison with similar indicators in healthy women were also assessed. It was found that most women with urinary tract pathology that were pregnant again, had complications of somatic (most often a combination of urinary tract pathology and chronic infectious diseases) and reproductive history (most often - miscarriages). Women with complications during pregnancy, pyelonephritis, anemia, and the threat of abortion were significantly more often registered in the main group $(\mathrm{p}<0.05)$. Women in the main group were significantly more likely to have premature births: $15.4 \%$ of women with acute pyelonephritis and $46.2 \%$ of women with chronic pyelonephritis, while all women in the control group gave birth on time $(\mathrm{P}<0.05)$. Significantly more women in the main group had complications in childbirth: most often - weakness of labor - I group 8 (6.2\%), II - 9 (6.9\%). Termination of pregnancy in the vast majority of women in the main group was physiological, cesarean delivery was completed in $3(2.3 \%)$ women in group I and $10(7.7 \%)$ women in group II. All women in the control group had timely, physiological births. The condition of newborns of mothers with pathology of the urinary system was often disturbed. A significant proportion of children from the main group (I $-5.4 \%, \mathrm{II}-10.0 \%$ ) required immediate resuscitation measures at birth and their transfer to specialized departments for further treatment.

Keywords: kidney diseases, pregnancy, retrospective analysis.

DOI https://doi.org/10.23856/4335

\section{Introduction}

In Ukraine, studies of genetic and demographic processes conducted in recent years have shown that the socially conditioned demographic crisis observed in the country is significantly exacerbated by perinatal complications. This is manifested in an increased incidence of lost pregnancies and the birth of unhealthy children in women with extragenital pathology (Veropotvelian MP, 2016; Shestakova T. S., 2012; Mandal D., 2017).

The relevance of the study of infectious diseases of the urinary system in obstetrics is due to the high prevalence of this pathology, as well as complications that occur during 
pregnancy, childbirth and postpartum and pose a danger to mother and fetus (Bounds KR, 2015; Hryhorenko AP, 2014; Samigullina AE, 2016; Sharhorodska Ye.B., 2018). Nowadays, almost $60 \%$ of pregnant women have diseases of the internal organs. Abnormalities in the development of the child are observed in extragenital diseases of the mother 4 times more often than in the general population. The relationship between the severity of the clinical course of the disease in pregnant women and the degree of fetal and neonatal disorders was found (Haistruk N.A., 2017; Limanskaya A.Yu., 2016; Olshevska O.V., 2016).

The role of extragenital diseases (diseases of internal organs) in the occurrence of obstetric complications (late preeclampsia, prematurity, uterine contractile dysfunction, etc.) in the development of perinatal pathology (Tillett J., 2015; Veropotvelian P. M., 2011; Wing D. A., 2014) has been convincingly proven.

Diseases of the urinary system in pregnant women are second only to extragenital diseases. Their frequency is from 0.1 to $7-10 \%$ and poses a serious danger to the normal development of pregnancy and fetus (Glaser A. P., 2015; Govoruha I. T., 2016; Talalaienko Yu. O., 2016). First of all, it is pyelonephritis, urolithiasis, abnormalities in the development of the kidneys and ureters, chronic cystitis, asymptomatic bacteriuria, chronic glomerulonephritis (Bahri A. El., 2015; Holubenko M. Yu., 2012). Most often there is a combination of several diseases of the urinary system (Kazemier B. M., 2015; Szweda H., 2016).

Most complications of the gestational period manifest in the second half of pregnancy, but the causes of their occurrence, which are due to a complex of placental dysfunction, are most often laid in the pre-pregnancy, implantation and early placental periods (Holubenko M. Yu., 2012). Pregnant women with pyelonephritis develop the following obstetric and perinatal complications: early toxicosis $(65.5 \%)$, placental dysfunction $(73.3 \%)$, preeclampsia $(78.3 \%)$, risk of miscarriage $(76.1 \%)$ and premature birth $(56.2 \%)$, low placentation $(76.1 \%)$, polyhydramnios $(76.7 \%)$, gestational anemia $(67.8 \%)$, fetal growth retardation $(17.1 \%)$, premature placental abruption (26.3\%). During childbirth they develop premature ejaculation of amniotic fluid (22.4\%), weakness of labor (72.3\%), obstetric bleeding $(47.1 \%)$. In the postpartum period they develop subinvolution of the uterus (26.3\%) (Godaly G., 2015; Haistruk N.A., 2017; Holubenko M. Yu., 2012; Romanenko T. H., 2016). The level of perinatal mortality and miscarriage increases by $2-3$ times (Hryhorenko A.P., 2014).

Scientific research and practical experience show that the issues of preserving reproductive health, reducing maternal and fetal losses, and especially the demographic situation go far beyond the medical field and have become a national interdisciplinary problem in Ukraine.

Improving the principles of pregnancy management and the use of optimal delivery help reduce infant mortality and morbidity. The analysis of the literature shows that not all reserves for the improvement of perinatal indicators are used. One such reserve is the improvement of measures to improve the preconceived health of the population of reproductive age. Screening of preconception perinatal risk and its active correction in women who have had negative consequences of previous pregnancies, allows to realize the positive results of the next pregnancy (Melenchuk L. M., 2019; Safonova I. M, 2015).

Therefore, the development of informative criteria for individual prediction of pregnancy and perinatal period is of great medical and social importance.

Thus, effective prevention of the pathological condition of the fetus in women with diseases of the urinary system requires a targeted study of maternal factors due to the influence of somatic pathology. Timely detection of women at risk will create a basis for the prognosis of the next pregnancy, reduce the level of perinatal pathology, which will have a significant medical and social effect. The obtained data will allow to improve the system of approaches 
to determining the risk groups of perinatal pathology and improve specialized care for women with diseases of the urinary system. As a result of this work, informative factors of high risk of perinatal pathology in women at risk with pathology of the urinary system will be identified.

The purpose of the research is to identify maternal factors of perinatal complications in women with kidney disease. To solve this goal, the following tasks were set:

1. To form contingents of women with pathology of the urinary system among the population of Lviv region.

2. Investigate the complications of pregnancy and childbirth in women with kidney disease.

3. Assess the condition of newborns in women with kidney disease.

\section{Selecting a group of women with pathology of the urinary system for this research}

To achieve this goal, we conducted an analysis of clinical, epidemiological, medical and statistical data of primary medical records. Selected maps of pregnant women with a clinical diagnosis of "Diseases of the urinary system" according to the International Classification of Diseases-10 (N010 - N099). The obtained indicators were compared with similar parameters of the control group: healthy women who gave birth to alive children in the maternity ward of the Regional Clinical Hospital of Lviv in 2014-2017: 100 healthy pregnant women who gave birth to children in the same period of time formed a control group. To assess the maternal factors of perinatal complications in women with diseases of the urinary system, the course of pregnancy and childbirth, gestational age at birth, assessment of the condition of children at birth were studied.

For the purpose of this study two groups of researched women were created - the main 130 pregnant women and the control 100 women (without extragenital pathology). The main group was divided into two groups: I - pregnant women with acute pyelonephritis (GP), this group included pregnant women, who were diagnosed with acute pyelonephritis for the first time during their pregnancy. Group II included pregnant women with chronic pyelonephritis (CP) - women who had diseases of the urinary system before pregnancy.

The women in the control group had no reproductive and somatic history of diseases and were healthy.

It should be noted that in the Regional Clinical Hospital of Lviv pregnant women with extragenital pathology from all Lviv region are concentrated. Statistical processing of research results was performed using computer programs «Statistica 6.0» and Excel 5.0 «. Differences were considered significant at $\mathrm{P}<0.05$.

\section{The course of pregnancy in women with diseases of the urinary system}

Analysis of archival documentation - maps of pregnant women in the obstetrics department of the Regional Clinical Hospital of Lviv for a period of (for) 4 years showed that most women in groups I and II were pregnant again, and the control group was dominated by women with the first pregnancy number $(\mathrm{P}<0.05)$, table 1 .

According to the results of a detailed retrospective analysis, it was proved that somatic diseases were diagnosed in the majority of patients of the main group. In 10 (7.7\%) women of the main group and in all $100(100.0 \%)$ women of the control group complications of somatic anamnesis were not registered $(\mathrm{p}<0.05)$. Significantly more often than the control group, women with kidney disease had a combination of pathology of the urinary system and chronic 
infectious diseases (58-44.6\%), diseases of the endocrine system (21-16.2\%), a combination of cardiovascular diseases and chronic infectious diseases (17-13.1\%), a combination of diseases of the cardiovascular and endocrine system (12-9.2\%), diseases of the cardiovascular system $(12-9.2 \%)$, a combination of pathology of the urinary system and endocrine pathology $(5-3.8 \%)(\mathrm{p}<0.05)$.

Table 1

The ordinal number of pregnancy in women with pathology of the urinary system

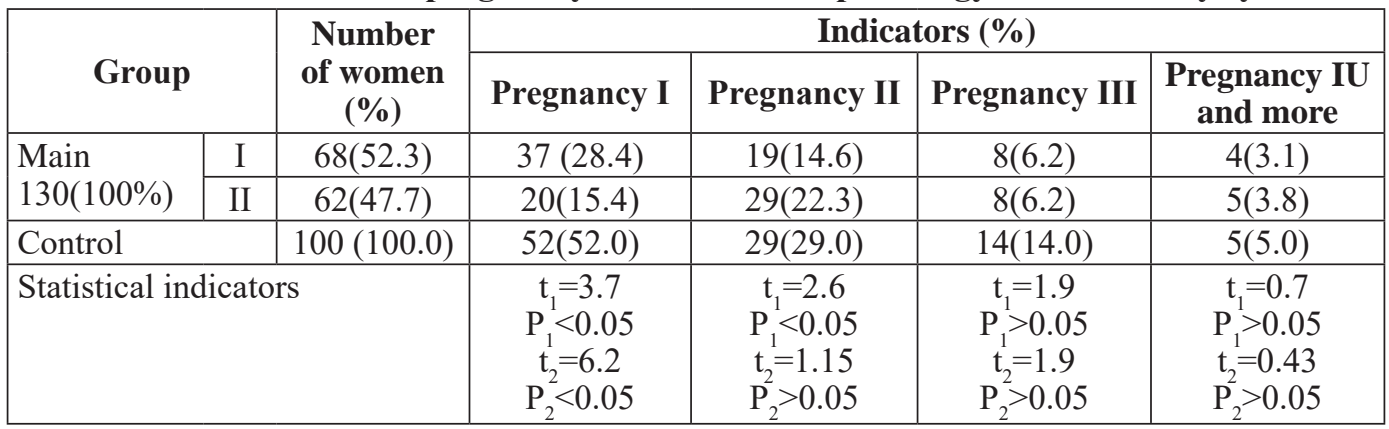

Note: $\mathrm{t}_{1} \cdot \mathrm{P}_{1}-$ comparison of I group with control; $\mathrm{t}_{2} \cdot \mathrm{P}_{2}-$ comparison of II group with control

Analysis of the spectrum of reproductive losses showed that $32(24.6 \%)$ women of I and $42(32.3 \%)$ women of group II had various complications. Thus, frozen pregnancies: in group I - $9(6.9 \%)$, in group II - $17(13.1 \%)$; ectopic pregnancy - in group I - 7 (5.4\%), in group II $-8(6.2 \%)$; unauthorized miscarriages - in group I - $13(10.0 \%)$, in group II -10 $(7.7 \%)$; medical abortions - in I - $3(2.3 \%)$, in II - 7 (5.4).

In women with acute and chronic pyelonephritis in the spectrum of reproductive losses in the first place were miscarriages $-10.0 \%$ and $7.7 \%$, respectively. In contrast to the women of the main group, in the control group - all patients - $100(100.0 \%)$ had no features of reproductive history $(\mathrm{p}<0.05)$.

In the sample of patients who were analyzed, a study of the peculiarities of the course of pregnancy of patients was conducted (Table 2).

Table 2

The course of pregnancy in women with pathology of the urinary system

\begin{tabular}{|c|c|c|c|c|}
\hline \multirow{2}{*}{ Indicators } & \multicolumn{2}{|c|}{ Main group, $130(100.0 \%)$} & \multirow{2}{*}{$\begin{array}{c}\text { Control } \\
\text { group, p. (\%) }\end{array}$} & \multirow{2}{*}{$\begin{array}{l}\text { Statistical } \\
\text { indicators }\end{array}$} \\
\hline & I. p (\%) & II. $p(\%)$ & & \\
\hline 1 & 2 & 3 & 4 & 5 \\
\hline Without complications & - & - & $90 / 90.0$ & $\begin{array}{l}\mathrm{t}_{1}=30.0 ; \mathrm{P}<0.05 \\
\mathrm{t}_{2}=30.0 ; \mathrm{P}<0.05\end{array}$ \\
\hline Early gestosis & $8(6.2)$ & $2(1.50$ & $2(2.0)$ & $\begin{array}{l}\mathrm{t}_{1}=1.65 ; \mathrm{P}>0.05 \\
\mathrm{t}_{2}=0.28 ; \mathrm{P}>0.05\end{array}$ \\
\hline Pre-eclamsia & $4(3.1)$ & $3(2.3)$ & - & $\begin{array}{l}\mathrm{t}_{1}=2.04 ; \mathrm{P}<0.05 \\
\mathrm{t}_{2}=1.75 ; \mathrm{P}>0.05\end{array}$ \\
\hline Early gestosis + anemia & - & $6(4.6)$ & $1(1.0)$ & $\begin{array}{l}\mathrm{t}_{\mathrm{t}}=1.0 ; \mathrm{P}>0.05 \\
\mathrm{t}_{2}=1.72 ; \mathrm{P}>0.05\end{array}$ \\
\hline Preeclampsia + anemia & - & $7(5.4)$ & - & $\begin{array}{c}\mathrm{t}_{1}=1.0 ; \mathrm{P}>0.05 \\
\mathrm{t}_{2}=2.72 ; \mathrm{P}<0.05\end{array}$ \\
\hline
\end{tabular}


Table 2 (Continued)

\begin{tabular}{|c|c|c|c|c|}
\hline 1 & 2 & 3 & 4 & 5 \\
\hline $\begin{array}{l}\text { Early gestosis }+ \\
\text { preeclampsia }\end{array}$ & $3(2.3)$ & $1(0.8)$ & - & $\begin{array}{l}\mathrm{t}_{1}=1.75 ; \mathrm{P}>0.05 \\
\mathrm{t}_{2}=1.03 ; \mathrm{P}>0.05\end{array}$ \\
\hline $\begin{array}{l}\text { Early preeclampsia }+ \text { threat } \\
\text { of abortion }\end{array}$ & $6(4.6)$ & $1(0.8)$ & $2(2.0)$ & $\begin{array}{l}\mathrm{t}_{1}=1.13 ; \mathrm{P}>0.05 \\
\mathrm{t}_{2}=0.75 ; \mathrm{P}>0.05\end{array}$ \\
\hline $\begin{array}{l}\text { Threat of termination of the } \\
\text { first half of pregnancy }\end{array}$ & $6(4.6)$ & $7(5.4)$ & $2(2.0)$ & $\begin{array}{c}\mathrm{t}_{1}=1.13 ; \mathrm{P}>0.05 \\
\mathrm{t}_{2}=1.4 ; \mathrm{P}>0.05\end{array}$ \\
\hline $\begin{array}{l}\text { Threat of interruption of } \\
\text { the second half }\end{array}$ & - & $8(6.2)$ & $1(1.0)$ & $\begin{array}{l}\mathrm{t}_{1}=1.0 ; \mathrm{P}>0.05 \\
\mathrm{t}_{2}=2.22 ; \mathrm{P}<0.05\end{array}$ \\
\hline Anemia & $7(5.4)$ & $11(8.5)$ & $2(2.0)$ & $\begin{array}{l}\mathrm{t}_{1}=1.4 ; \mathrm{P}>0.05 \\
\mathrm{t}_{2}=2.31 ; \mathrm{P}<0.05\end{array}$ \\
\hline $\begin{array}{l}\text { Threat of termination of the } \\
\text { second half of pregnancy }+ \\
\text { anemia }\end{array}$ & - & $9(6.9)$ & - & $\begin{array}{l}\mathrm{t}_{1}=1.0 ; \mathrm{P}>0.05 \\
\mathrm{t}_{2}=3.1 ; \mathrm{P}<0.05\end{array}$ \\
\hline $\begin{array}{l}\text { Preeclampsia }+ \text { threat of } \\
\text { termination of the first and } \\
\text { second half of pregnancy }\end{array}$ & - & $5(3.8)$ & - & $\begin{array}{l}\mathrm{t}_{1}=1.0 ; \mathrm{P}>0.05 \\
\mathrm{t}_{2}=2.27 ; \mathrm{P}<0.05\end{array}$ \\
\hline Polyhydramnios & $2(1.5)$ & - & - & $\begin{array}{l}\mathrm{t}_{1}=1.41 ; \mathrm{P}>0.05 \\
\mathrm{t}_{2}=1.0 ; \mathrm{P}>0.05\end{array}$ \\
\hline Lowhydramnios & - & $2(1.5)$ & - & $\begin{array}{l}\mathrm{t}_{1}=1.0 ; \mathrm{P}>0.05 \\
\mathrm{t}_{2}=1.0 ; \mathrm{P}>0.05\end{array}$ \\
\hline Pyelonephritis & $32(24.6$ & $62(47.7)$ & - & $\begin{array}{c}\mathrm{t}_{1}=6.51 ; \mathrm{P}<0.05 \\
\mathrm{t}_{2}=10.89 ; \mathrm{P}<0.05\end{array}$ \\
\hline Total & $68(52.3)$ & $62(47.7)$ & $100(100.0)$ & \\
\hline
\end{tabular}

Note: $t_{1} \cdot P_{1}-$ comparison of I group with control; $t_{2} . P_{2}-$ comparison of II group with control

According to the results of the analysis of pregnancy indicators, all 130 (100.0\%) women of the main group had complications. The main complications were in group I - pyelonephritis $-32(24.6 \%)$ cases (a), and in women of group II, with chronic pyelonephritis recorded 11 $(8.5 \%)$ cases of anemia, $8(6.2 \%)$ - threats of termination of the first half of pregnancy, $7(5.4 \%)$ cases of preeclampsia in combination with anemia, $5(3.8 \%)$ with the threat of abortion of the first and second half of pregnancy. In contrast to women in the main group, in the control group significantly more patients $-90(90.0 \%)$ did not notice pregnancy $(\mathrm{p}<0.05)$. And the number of complications there was significantly lower $(\mathrm{p}<0.05)$.

\section{Completion of pregnancy and childbirth. Assessment of the condition of children at birth in women with diseases of the urinary system}

The analysis of the results of termination of pregnancy showed that women of the main group II had significantly more frequent recurrences, as well as patients of group II in $10(7.7 \%)$ cases - completion of childbirth by cesarean section $(\mathrm{p}<0.05)$ (table 3$)$.

When studying the course of childbirth in women of both groups a significantly higher percentage of complications in women of the main group compared to the control was found. $28(21.5 \%)$ women with pathology of the urinary system and $97(07 \%)$ women of the control group did not show any features of childbirth $(\mathrm{p}<0.05)$. 
Table 3

Characteristics of childbirth in women with renal pathology

\begin{tabular}{|c|c|c|c|c|c|c|}
\hline \multirow[b]{2}{*}{$\begin{array}{l}\text { Group of } \\
\text { women }\end{array}$} & \multirow{2}{*}{\multicolumn{2}{|c|}{$\begin{array}{c}\text { Number of } \\
\text { women p(\%) }\end{array}$}} & \multicolumn{4}{|c|}{ Indicators пा(\%) } \\
\hline & & & \multirow{2}{*}{$\begin{array}{c}\begin{array}{c}\text { First } \\
\text { childbirth }\end{array} \\
37(28.5)\end{array}$} & \multirow{2}{*}{$\begin{array}{c}\begin{array}{c}\text { Second } \\
\text { childbirth }\end{array} \\
31(23.8)\end{array}$} & \multirow{2}{*}{$\begin{array}{c}\begin{array}{c}\text { Physiological } \\
\text { childbirth }\end{array} \\
65(50.0)\end{array}$} & \multirow{2}{*}{$\frac{\text { C-section }}{3(2.3)}$} \\
\hline Main & GP & $68(52.3)$ & & & & \\
\hline $130(100.0)$ & $\mathrm{HP}$ & $62(47.7)$ & $20(15.4)$ & $42(32.3)$ & $52(40.0)$ & $10(7.7)$ \\
\hline Control & \multicolumn{2}{|c|}{$100(100.0)$} & $52(52.0)$ & $48(48.0)$ & $100(100.0)$ & - \\
\hline \multicolumn{3}{|c|}{ Statistical indicators } & $\begin{array}{l}\mathrm{t}_{1}=3.69 \\
\mathrm{P}_{1}<0.05 \\
\mathrm{t}_{2}=6.19 \\
\mathrm{P}_{2}<0.05\end{array}$ & $\begin{array}{l}\mathrm{t}_{1}=3.88 \\
\mathrm{P}_{1}<0.05 \\
\mathrm{t}_{2}=2.43 \\
\mathrm{P}_{2}<0.05\end{array}$ & $\begin{array}{c}\mathrm{t}_{1}=11.4 \\
\mathrm{P}_{1}<0.05 \\
\mathrm{t}_{2}=13.96 \\
\mathrm{P}_{2}<0.05\end{array}$ & $\begin{aligned} \mathrm{t}_{1} & =1.75 \\
\mathrm{P}_{1} & >0.05 \\
\mathrm{t}_{2} & =3.29 \\
\mathrm{P}_{2} & <0.05\end{aligned}$ \\
\hline
\end{tabular}

Note: $\mathrm{t}_{1} \cdot \mathrm{P}_{1}-$ comparison of group I with the control; $\mathrm{t}_{2} \cdot \mathrm{P}_{2}-$ comparison of group II with the control

Significantly more women in the main group had a weakness of labor: Group I - 8 $(6.2 \%)$, II - $9(6.9 \%)$ against $1(1.6 \%)$ in the control group; manure defect - group I $8(6.2 \%)$, II $-7(5.5 \%)$ in the absence of these complications in the control group $(p<0.05)$. In the main group, births occurred significantly more often: Group I $6(4.6 \%)$, II $-29(22.3 \%)(p<0.05)$. It should be noted that much more often premature births were in group I of women with chronic pyelonephritis. All women in the control group had timely births (table 4).

Table 4

Features of childbirth in women with pathology of the urinary system

\begin{tabular}{|c|c|c|c|c|c|c|c|c|c|}
\hline \multicolumn{4}{|c|}{ Indicators } & \multicolumn{6}{|c|}{ Complications during childbirth } \\
\hline \multirow{2}{*}{\multicolumn{2}{|c|}{$\begin{array}{c}\text { Group of } \\
\text { women, p. }(\%)\end{array}$}} & 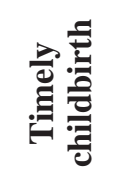 & ت & 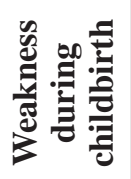 & 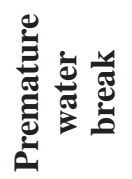 & 异莽 & : & 䓀 & 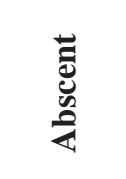 \\
\hline & & $\Pi(\%)$ & $\Pi(\%)$ & $\Pi(\%)$ & $\Pi(\%)$ & $\Pi(\%$ & $\Pi(\%)$ & $\Pi(\%)$ & $\Pi(\%)$ \\
\hline \multirow{2}{*}{$\begin{array}{l}\text { Main } \\
130 \\
(100.0)\end{array}$} & $\begin{array}{l}I-68 \\
(52.3)\end{array}$ & $\begin{array}{c}62 \\
(47.7) \\
\end{array}$ & $6(4.6)$ & $\begin{array}{c}18 \\
(13.8) \\
\end{array}$ & $8(6.2)$ & $8(6.2)$ & $2(1.5)$ & $4(3.1)$ & $\begin{array}{c}28 \\
(21.5) \\
\end{array}$ \\
\hline & $\begin{array}{l}\text { П-62 } \\
(47.7)\end{array}$ & $\begin{array}{c}33 \\
(25.4)\end{array}$ & $\begin{array}{c}29 \\
(22.3)\end{array}$ & $\begin{array}{c}15 \\
(11.5)\end{array}$ & $9(6.9)$ & $7(5.5)$ & $3(2.3)$ & $\begin{array}{c}28 \\
(21.5)\end{array}$ & - \\
\hline \multicolumn{2}{|c|}{$\begin{array}{l}\text { Control } \\
n=100(100.0)\end{array}$} & $\begin{array}{c}100 \\
(100.0)\end{array}$ & - & $2(2.0)$ & $1(1.0)$ & - & - & - & $\begin{array}{c}97 \\
(97.0)\end{array}$ \\
\hline \multicolumn{2}{|c|}{$\begin{array}{l}\text { Statistical indi- } \\
\text { cators }\end{array}$} & $\begin{array}{l}\mathrm{t}_{1}=11.9 \\
\mathrm{P}_{1}<0.05 \\
\mathrm{t}_{2}=19.5 \\
\mathrm{P}_{2}<0.05\end{array}$ & $\begin{aligned} \mathrm{t}_{1} & =2.5 \\
\mathrm{P}_{1} & <0.05 \\
\mathrm{t}_{2} & =6.1 \\
\mathrm{P}_{2} & <0.05\end{aligned}$ & $\begin{array}{l}\mathrm{t}_{1}=3.54 \\
\mathrm{P}_{1}<0.05 \\
\mathrm{t}_{2}=3.03 \\
\mathrm{P}_{2}<0.05\end{array}$ & $\begin{array}{l}\mathrm{t}_{1}=2.22 \\
\mathrm{P}_{1}<0.05 \\
\mathrm{t}_{2}=2.42 \\
\mathrm{P}_{2}<0.05\end{array}$ & $\begin{array}{l}\mathrm{t}_{1}=2.93 \\
\mathrm{P}_{1}<0.05 \\
\mathrm{t}_{2}=2.75 \\
\mathrm{P}_{2}<0.05\end{array}$ & $\begin{aligned} \mathrm{t}_{1} & =1.4 \\
\mathrm{P}_{1} & >0.05 \\
\mathrm{t}_{2} & =1.75 \\
\mathrm{P}_{2} & >0.05\end{aligned}$ & $\begin{array}{c}\mathrm{t}_{1}=2.04 \\
\mathrm{P}_{1}<0.05 \\
\mathrm{t}_{2}=5.97 \\
\mathrm{P}_{2}<0.05\end{array}$ & $\begin{array}{l}\mathrm{t}_{1}=18.9 \\
\mathrm{P}_{1}<0.05 \\
\mathrm{t}_{2}=56.8 \\
\mathrm{P}_{2}<0.05\end{array}$ \\
\hline
\end{tabular}

Note: $t_{1} \cdot P_{1}-$ comparison of I group with control; $t_{2} \cdot P_{2}-$ comparison of II group with control

According to the results of the assessment of the condition of children at birth, it was found that the number of children of women in the main group with a score on the V. Apgar scale was: Group I satisfactory - 7-10 points - 53 (40.8\%) children; mild and severe hypoxia 6 or less points - 15 (11.5\%) newborns; and in group II - satisfactory condition - 7-10 points - 37 $(28.46 \%)$ children; mild and severe hypoxia 6 or less points $-25(19.2 \%)$ children. 
A significant proportion of children from mothers with pathology of the urinary system required transfer to specialized intensive care units: 7 (5.4\%) from women of group I and 13 $(10.0 \%)$ - group II. In one case $(0.8 \%)$ mortality was noted. All children from the mothers of the control group were discharged home in satisfactory condition $(\mathrm{P}<0.05)$ (table 5$)$.

A significant proportion of children from mothers with pathology of the urinary system required transfer to specialized intensive care units: 7 (5.4\%) from women of group I and 13 $(10.0 \%)$ - group II. In one case $(0.8 \%)$ mortality was noted. All children from the mothers of the control group were discharged home in satisfactory condition $(\mathrm{P}<0.05)$ (table 5).

Table 5

Assessment of the condition of newborns from mothers with pathology of the urinary system

\begin{tabular}{|c|c|c|c|c|c|c|}
\hline \multirow{3}{*}{\multicolumn{2}{|c|}{$\begin{array}{c}\text { Group of } \\
\text { children } \\
\text { n (\%) }\end{array}$}} & \multicolumn{5}{|c|}{ Indicators (number of children. p(\%) } \\
\hline & & \multicolumn{2}{|c|}{$\begin{array}{c}\text { Evaluation according to } \\
\text { V. Apgar }\end{array}$} & \multirow{3}{*}{$\begin{array}{c}\text { Discharge } \\
61(46.9)\end{array}$} & \multirow{3}{*}{$\begin{array}{c}\begin{array}{c}\text { Transfer to } \\
\text { reanimation }\end{array} \\
7(5.4)\end{array}$} & \multirow{3}{*}{$\begin{array}{c}\text { Died } \\
-\end{array}$} \\
\hline & & 6 б. $\mathrm{i}<$ & 7 б. i > & & & \\
\hline \multirow{2}{*}{$\begin{array}{l}\text { Main } \\
\mathrm{p}=130 \\
(100 \%)\end{array}$} & $\begin{array}{c}\mathrm{I} \\
68(52.3)\end{array}$ & $15(11.5)$ & $53(40.8)$ & & & \\
\hline & $\begin{array}{c}\Pi \\
62(47.7)\end{array}$ & $25(19.2)$ & $37(28.46)$ & $48(36.9)$ & $13(10.0)$ & $1(0.8)$ \\
\hline \multicolumn{2}{|c|}{$\begin{array}{l}\text { Control } \\
p=100(100 \%)\end{array}$} & - & $100(100.0)$ & $100(100.0)$ & - & - \\
\hline \multicolumn{2}{|c|}{$\begin{array}{l}\text { Statistical indica- } \\
\text { tors }\end{array}$} & $\begin{array}{l}\mathrm{t}_{1}=4.11 \\
\mathrm{P}_{1}<0.05 \\
\mathrm{t}_{2}=5.56 \\
\mathrm{P}_{2}<0.05\end{array}$ & $\begin{array}{l}\mathrm{t}_{1}=13.7 \\
\mathrm{P}_{1}<0.05 \\
\mathrm{t}_{2}=18.06 \\
\mathrm{P}_{2}<0.05\end{array}$ & $\begin{array}{l}\mathrm{t}_{1}=12.13 \\
\mathrm{P}_{1}<0.05 \\
\mathrm{t}_{2}=14.91 \\
\mathrm{P}_{2}<0.05\end{array}$ & $\begin{aligned} \mathrm{t}_{1} & =2.72 \\
\mathrm{P}_{1} & <0.05 \\
\mathrm{t}_{2} & =3.8 \\
\mathrm{P}_{2} & <0.05\end{aligned}$ & $\begin{array}{l}\mathrm{t}_{2}=1.02 \\
\mathrm{P}_{2}>0.05\end{array}$ \\
\hline
\end{tabular}

Note: t1. P1 - comparison of group I with the control; t2. P2- comparison of group II with the control.

Therefore, after conducting a comparative analysis of reproductive losses, somatic history in women with pathology of the urinary system and studying the results of the course and completion of pregnancy, as well as complications of childbirth in such women living in Lviv region, we can draw the following conclusions.

It has been proved that women with pathology of the urinary system are at risk of obstetric complications. Significant differences were found in the comparison of pregnancy parity in women of the main and control groups $(\mathrm{P}<0.05)$ : most women in both surveyed groups were pregnant again: $74(56.9 \%)$ in the main group, and $22(73.3 \%)$ in the control group with most women pregnant for the first time. There were significant differences in the rates of termination of pregnancy and complications during childbirth: women in the main group were significantly more likely to have premature births (15.4\% of women with GP and $46.2 \%$ of women with CP), while all women in the control group gave birth in term $(\mathrm{P}<0.05)$.

\section{Conclusions}

1. Significant differences were found in the comparison of the ordinal number of pregnancy in women of the main and control groups: a significant number of women in the main group were pregnant again: $74(56.9 \%)$, and the control group was dominated by first-born $22(73.3 \%),(\mathrm{P}<0.05)$. The majority of patients in the main group $(120-92.3 \%)$ had somatic 
diseases. The most common was the combination of pathology of the urinary system and chronic infectious diseases $(58-44.6 \%)$. All women in the control group were healthy $(\mathrm{p}<0.05)$.

2. It was found that $32(24.6 \%)$ women with acute pyelonephritis and $42(32.3 \%)$ women with chronic pyelonephritis had complications of reproductive history, most often - miscarriages: $10.0 \%$ and $7.7 \%$, respectively $(\mathrm{p}<0.05)$.

3. Analysis of the course of pregnancy in the studied women showed a much higher percentage of complications in pregnant women of the main group. The main complications were in group I - pyelonephritis - $32(24.6 \%)$ cases. Significantly more often women of group II had chronic pyelonephritis, anemia - $11(8.5 \%)$, the threat of termination of the first half of pregnancy $-8(6.2 \%)$, preeclampsia in combination with anemia $-7(5.4 \%)$ and the threat of termination of the first and second half of pregnancy $5(3.8 \%)$. In the control group, $90(90.0 \%)$ women did not note the peculiarities of pregnancy $(\mathrm{p}<0.05)$.

4. There were significant differences in the rates of termination of pregnancy and complications during childbirth: women in the main group were significantly more likely to have premature births (15.4\% of women with acute pyelonephritis and $46.2 \%$ of women with chronic pyelonephritis), while all women in the control group gave birth on time $(\mathrm{P}<0.05)$. Significantly more women in the main group had a weakness of labor: Group I $8(6.2 \%)$, Group 9 $(6.9 \%)$ against $1(1.6 \%)$ in the control group; defect of manure I group $8(6.2 \%)$, II 7 (5.5\%) in the absence of these complications in the control group $(p<0.05)$.

5. Pregnancy termination in the vast majority of women in the main group was physiological: in $65(50.0 \%)$ women of group I and in $52(40.0 \%)$ women of group II $(\mathrm{P}<0.05)$. Respectively, cesarean delivery was completed in 3 (2.3\%) women from groups I and $10(7.7 \%)$ from group 2. All women in the control group had timely, physiological births.

6. The obtained results indicate that the condition of newborns from mothers with pathology of the urinary system, was often disturbed and was differed from similar indicators in almost healthy newborns. Estimate on the V. Apgar scale was the following: in group I 6 or less points had $15(11.5 \%)$ newborns; and in group II -6 or less points $-25(19.2 \%)$ children. A significant proportion of children from the main group (I -5.4\%, II - 10.0\%) needed immediate resuscitation measures at birth and their transfer to specialized departments for further treatment.

\section{Prospects for further research}

The solutions proposed in the paper are promising in terms of further possibility to determine the informative range of risk factors for perinatal pathology in women with diseases of the urinary system to improve the comprehensive prevention of this pathology.

\section{References}

Bahri A. El., Janane A., Chafiki J. et al. (2015). Acute pyelonephritis in pregnant women: place of medical treatment and indications for drainage of the upper urinary tract (Are there predictive clinical, biological and radiological factors to make the drainage acceptable?). Pan. Afr. Med. J. 22: 324. DOI: 10.11604/pamj.2015.22.324.7262.

Bounds K. R., Newell-Rogers M. K., Mitchell B. M. (2015). Four pathways involving innate immunity in the pathogenesis of preeclampsia. Front. Cardiovasc. Med. 2: 20. DOI: 10.3389/ fcvm.2015.00020.

Glaser A. P., Schaeffer A. J. (2015). Urinary Tract Infection and Bacteriuria in Pregnancy. Urol. Clin. North. Am. 42, 4: 547-60. DOI: 10.1016/j.ucl.2015.05.004.

Godaly G., Ambite I., Svanborg C. (2015). Innate immunity and genetic determinants of 
urinary tract infection susceptibility. Curr. Opin. Infect. Dis. 28, 1: 88-96. - DOI: 10.1097/ QCO.0000000000000127.

Govoruha I. T., Stepanenko T.A. (2013). Faktory riska razvitiya pielonefrita u beremennyh $s$ bessimptomnoj bakteriuriej. [Risk factors for the development of pyelonephritis in pregnant women with asymptomatic bacteriuria] Medyko-sotsialni problemy simi. 18; 4: 16-18. [in Ukrainian].

Haistruk N.A., Suprunova T.V., Nadezhdin M.V., Ponina S.I. (2017). Osoblyvosti perebihu vahitnosti ta stan ploda u vahitnykh z hestatsiinym ta khronichnym piielonefrytom. [Peculiarities of pregnancy and fetal condition in pregnant women with gestational and chronic pyelonephritis]. Journal of Education, Health and Sport. 7, 1: 423-436. [in Ukrainian].

Holubenko M. Yu. (2012). Vyvchennia etiolohichnykh chynnykiv PD u zhinok z piielonefrytom. [Study of etiological factors of PD in women with pyelonephritis]. Aktualni problemy transportnoi medytsyny: navkolyshnie seredovyshche; profesiine zdorovia; patolohiia. 2: 87-91. [in Ukrainian].

Hryhorenko A.P., Shymanska-Horbatiuk O.H., Shatkovska N.S. [ta in.]. (2014). Vahitnist ta infektsii sechovyvidnoi systemy. [Pregnancy and urinary tract infections]. Medicinskie aspekty zdorov'ya zhenshchiny 6: 24-32. [in Ukrainian].

Kazemier B. M., Koningstein F. N., Schneeberger C. et al. (2015). Maternal and neonatal consequences of treated and untreated asymptomatic bacteriuria in pregnancy: a prospective cohort study with an embedded randomised controlled trial. Lancet Infect. Dis. 15, 11: 1324-1333. DOI: 10.1016/S1473-3099(15)00070-5.

Limanskaya A.YU., Shevchuk E.V., Ogorodnik A.A., Davydova YU.V. (2016). Prekoncepcionnaya profilaktika infekcij mochevyh putej $u$ zhenshchin gruppy vysokogo riska: rezerv snizheniya perinatal'nyh i akusherskih oslozhnenij. [ Preconception prevention of urinary tract infections in high-risk women: a reserve for reducing perinatal and obstetric complications]. Perynatolohiia ta pediatriia. 2: 28-31. http://nbuv.gov.ua/UJRN/perynatology_2016_2_9. [in Ukrainian].

Mandal D., Saha M. M., D. K. (2017). Pal Urological disorders and pregnancy: an overall experience. Urol Ann. 9, 1: 32-36. DOI: 10.4103/0974-7796.198901.

Melenchuk L. M., Chorna L.B. (2019). Rozrobka systemy efektyvnoho prohnozuvannia, rannoi diahnostyky i profilaktyky perynatalnoi patolohii v zhinok iz patolohiieiu sechovydilnoi systemy zalezhno vid henotypu polimorfnykh variantiv hena VEGF. [Development of a system for effective prediction, early diagnosis and prevention of perinatal pathology in women with pathology of the urinary system depending on the genotype of polymorphic variants of the VEGF gene]. Aktualni pytannia pediatrii, akusherstva ta hinekolohii. 1: 119-125. DOI: https://doi.org/10.11 603/24116-4944.2019.1.10198. [in Ukrainian].

Olshevska O.V., Olshevskyi V.S. (2016). Osoblyvosti fetalnoi adaptatsii pry khronichnomu piielonefryti ta preeklampsii na tli khronichnoho piielonefrytu. [Features of fetal adaptation in chronic pyelonephritis and preeclampsia on the background of chronic pyelonephritis]. Ukrainskyi zhurnal khirurhii. 1-2 (30-31): 68-71. [in Ukrainian].

Romanenko T. H. (2016). Korektsiia PD u vahitnykh z piielonefrytom. [Correction of PD in pregnant women with pyelonephritis.] Zdorov'e zhenshchiny. 1: 86-90. [in Ukrainian].

Safonova I. M. (2015). Postnatalni klinichni rezultaty riznykh ekhohrafichnykh variantiv anomalii sechovydilnoi systemy ploda: ohliad literatury $i$ analiz serii vypadkiv.[Postnatal clinical results of various ultrasound variants of fetal urinary system abnormalities: literature review and case series analysis]. Ukrainskyi radiolohichnyi zhurnal. 23, 1: 80-83. http://nbuv.gov.ua/ UJRN/URLZh_2015_23_1_16. [in Ukrainian]. 
Samigullina A. E., Otogonova ZH.K. (2016). Rol' pielonefritov v razvitii akusherskih oslozhnenij: obzor literatury. [The role of pyelonephritis in the development of obstetric complications: a literature review] Izvestiya vuzov. 7. 1: 36-38. [in Kyrgystan].

Sharhorodska Ye.B., Shkolnyk O.S. (2018). Retrospektyvnyi analiz perebihu vahitnosti v zhinok, shcho narodyly ditei iz vrodzhenoiu patolohiieiu systemy krovoobihu. [Retrospective analysis of pregnancy in women who gave birth to children with congenital pathology of the circulatory system]. Aktualni pytannia pediatrii, akusherstva ta hinekolohii. 2: 100-104. DOI: https://doi. org/10.11603/24116-4944.2018.2.9206. [in Ukrainian].

Shestakova T. S. (2012). Osobennosti gestacionnyh oslozhnenij u beremennyh s hronicheskim pielonefritom. [Features of gestational complications in pregnant women with chronic pyelonephritis]. Aktualni pytannia farmatsevtychnoi i medychnoi nauky ta praktyky. 2, 2: 163. [in Ukrainian].

Szweda H., Jóźwik M. (2016). Urinary tract infections during pregnancy - an updated overview. Dev. Period. Med. 20, 4: 263-272.

Talalaienko Yu. O., Yulish Ye. I., Talalaienko O. K. (2014). Piielonefryt, platsenta i novonarodzhenyi : ohliad literatury. [Pyelonephritis, placenta and newborn: a review of the literature]. Medyko-sotsialni problemy simi.19, 1: 98-103. [in Ukrainian].

Tillett J. (2015). Increasing morbidity in the pregnant population in the United States 29, 3: 191-193. DOI: 10.1097/JPN.0000000000000116.

Veropotvelian M.P., Kodunov L. O., Pohuliai Yu. S. (2016). Sezonni osoblyvosti formuvannia khromosomnoi patolohii u Tsentralnomu ta Pivdenno-Skhidnomu rehionakh Ukrainy: retrospektyvnyi analiz za 20 rokiv. [Seasonal features of chromosomal pathology formation in the Central and South-Eastern regions of Ukraine: a retrospective analysis for 20 years]. Zdorove zhenshchynul4: 91-97. http://nbuv.gov.ua/UJRN/Zdzh_2016_4_17.

Veropotvelian P. M., Vyshnevskyi I. Ye., Veropotvelian M. P. ta in. (2011). Suchasnyi pohliad na perebih vahitnosti ta polohiv, uskladnenyi piielonefrytom : ohliad literatury ta vlasni doslidzhennia. [Modern view of pregnancy and childbirth complicated by pyelonephritis: a review of the literature and our own research]. Pediatriia, akusherstvo ta hinekolohiia. 73, 4: 202-210. [in Ukrainian].

Wing D. A., Fassett M. J., Getahun D. (2014). Acute pyelonephritis in pregnancy: an 18-year retrospective analysis. Am. J. Obstet. Gynecol. 210, 3: 219.e1-219.e6. DOI: 10.1016/j. ajog.2013.10.006. 